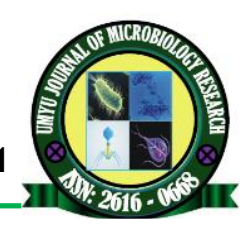

\title{
Prevalence of Human Papilloma Virus among women of child bearing Age in Yola Adamawa State, Nigeria
}

\author{
Nafisat Adamu Kachalla ${ }^{1 *}$, Halima Isa $^{2}$, Mohammed Bashir ${ }^{3}$, Shinjawa Yunana ${ }^{4}$ \\ ${ }^{1-3}$ Department of Microbiology, School of life sciences, Modibbo Adama University of Technology Yola. \\ Adamawa State, Nigeria. \\ ${ }^{4}$ Heamotology Department, Specialist Hospital Yola. Adamawa State Nigeria. \\ "Corresponding Author: Nafisat A. Kachalla, Email: nafisaadakachalla@gmail.com; Phone
} no. +2340739259693

\begin{abstract}
Epidemiological, molecular and clinical evidences have shown that cervical cancer is caused by the human papilloma-virus HPV), especially genotype 1618 and 45 . This study aims to survey the prevalence of high-risk types of HPV 16 18/45 among women of child-bearing age. Three hundred 300) women aged 18 years and above were randomly selected from the community and patients attending Specialist Hospital Yola (S.H.Y) and Federal Medical Center (F.M.C) Yola, Adamawa State. Relevant sexual and socio-demographic information was obtained from each subject using a questionnaire. High Vaginal swab samples were collected and analyzed using APTIMA Assay to identify the high-risk HPV genotype 16, 18 and 45 . Out of the 300 samples analyzed, 56 (18.7\%) were positive, $238(79.3 \%)$ were negative for HPV and $6(2 \%)$ are invalid. Out of the positive samples obtained, $29(51 \%)$ were HPV 16 while $27(48.2 \%)$ were HPV 18/45. The study also showed that the age grade of $24-41$ years had the highest prevalence of $25.6 \%$. No positive sample was found among age grades of $18-23$. The result shows that HPV prevalence was significantly associated with the number of sexual partners $(P=0.009)$.

Keywords Cervical-cancer, Human papilloma virus, High vaginal swab, high risk, sexually transmitted, APTIMA assay.
\end{abstract}

\section{INTRODUCTION}

Human Papilloma virus (HPV) infection is caused by a human Papilloma virus, a DNA virus from the Papovoviridae family. HPV is a common virus that affects both females and males. Most sexually active men and women will probably acquire a genital HPV infection at some point in their lives (Cohen, 2005). Most types of HPV are harmless, do not cause any symptoms and are self-limiting (CDC, 2003). HPV infection on the genitalia is the most common viral sexually transmitted disease, and it has been estimated that at least $50 \%$ of sexually active adults have had a genital HPV infection. Cohort studies indicate that genital HPV infection with oncogenic types is mostly transient and that only a small proportion of those infected become carriers and then develop cervical intraepithelial neoplasia (Hildshein et al.,1994). There are fourteen HPV genotypes that are considered pathogenic or high-risk for cervical cancer disease. Multiple studies have linked genotypes $16,18,31,33,35,39,45,51,52,56,58$, 59,66 and 68 to disease progression (Monsonego et al., 2003). Women with an infection with one of these types have an increased risk for developing severe dysplasia or cervical carcinoma. HPV infections are very common and most women will clear HPV infections within 6-12 months. The presence of HPV nucleic acid does not mean that cervical dysplasia or cervical cancer is present. However, an effective approach for detecting cervical disease is to target those oncogenic elements of HPV that foster persistent viral infection and cellular transformation (Monsonego et al., 2003).

Studies have shown that different types of high-risk HPV confer different levels of risk for developing severe dysplasia or cervical carcinoma. Globally, HPV types 16,18 and 45 are associated with approximately $80 \%$ of all invasive cervical cancers. These three types are found in $75 \%$ of squamous cell carcinomas, with type 16 alone found in over $60 \%$ of all squamous cell carcinomas. In adenocarcinomas, HPV types-16, 18 and 45 are found in $80-94 \%$ of cases, with types 18 and 45 composing almost half of these infections. The presence of HPV type 18 in an early stage of cervical cancer has been associated with a poor prognosis. HPV type 18 and 45 are under-reported in precancerous lesions, which may be caused by the presence of occult lesion of the cervical canal inaccessible to colposcopy examination (Safaein et al., 2009). 

In women infected with HPV 16 and or 18 , the cumulative risk of developing cervical diseases is 10- fold higher than other risk types (Walboomer et al., 1999).

Incidence rate of cervical cancer in Nigeria is $25 / 100,000$ while the reported prevalence rate for HPV in the general population is $26.3 \%$. The incidence of HPV in women with cervical cancer is reported to be $24.8 \%$. In most, cancer of the cervix, especially in developing countries, present at advanced stages when curative measures are unlikely to be successful (Thomas et al., 2004).

Proper determination and typing of high-risk HPV will help know the prevalence of HPV and create awareness, early detection, and encourage women to prevent the spread of cervical cancer. Therefore, it becomes imperative to determine the high-risk type of human Papilloma-virus among women of child bearing age in the state.

\section{MATERIALS AND METHODS}

\section{Study Area}

The research was carried in Yola, Adamawa State capital. Adamawa is a state in North Eastern Nigeria. It lays between $80^{\circ} \mathrm{N}$ and $11 \mathrm{~N}$ and longitude 11.50 and $13.50 \mathrm{E}$. It was formed in 1991 from part of Gongola State with four administrative divisions namely: Adamawa, Ganye, Mubi and Numan. It is one of the thirty-six (36) States which constitute the Federal Republic of Nigeria. The State shares border with Gombe State to the North, and Borno State to the North East, while to the West it is bordered with Taraba State as well as the Republic of Cameroon to the East (adamawastate.com).

\section{Ethical consideration}

Ethical approval was obtained from the State Ministry of Health Yola Adamawa with reference number $\mathrm{S} / \mathrm{MOH} / 1331 / 1$ and Federal Medical Center Yola, Adamawa State, reference number FMCY ISUB/96NOL.11XX and Specialist Hospital Yola Reference number ADS/SHY/SUB/77/VOL. 1 . Informed consent approval was signed by the participating population before collecting samples from them.

\section{Demographical Data of Participant}

A questionnaire was given to obtain demographical data of the individual. The questionnaires were filled with individuals' data such as age, marital status, and occupation.

\section{Study population}

The study targeted women of child-bearing ages of 18 years and above within the communities and those attending the two major Hospitals (F.M.C and S.H.Y) for various medical assistance. Sample size determination The sample size was determined using the formula

$$
N=\frac{\left.z^{2} p 1-p\right)}{d^{2}}
$$

Where; $\mathrm{N}=$ the sample size, $\mathrm{P}=$ Expected prevalence or proportion. $Z=$ Statistic for a level of confidence which is 1.96 at $95 \%$. $d=$ Precision. For this study, $\mathrm{p}=25 \%$ based on previous prevalence by (Naing et al., 2006), 300 was obtained as the sample size.

\section{Specimen Collection and Processing}

With a sterile swab stick, high vaginal swab samples were obtained from the participants and the swab sticks were returned aseptically to the vials before processing. The samples are then separately transferred into a specimen container containing specimen transport media (S.T.M.) that lyses the cells before the analysis (APTIMA, 2012).

\section{Assay Procedure}

Four hundred microliter $400 \mu \mathrm{l}$ of each sample was pipetted into a container, $100 \mu$ l of captured reagent was added, A barcode scanner was used to scan each sample before loading into the APTIMA HPV 16 18/45 Assay Machine, it was incubated for 35 minutes at $62{ }^{\circ} \mathrm{C}$, after 35 minutes the temperature was reduced to $25{ }^{\circ} \mathrm{C}$ for hybridization to occur, the supernatant was aspirated. $1.0 \mathrm{ml}$ of detergent was added, vortexed, centrifuged and the supernatant aspirated. The temperature was raised to $62{ }^{\circ} \mathrm{C}$ and $75 \mu \mathrm{l}$ of amplification reagent was added and $200 \mu$ of oil was also added mixed and incubated for 10 minutes then the temperature was reduced to $42{ }^{\circ} \mathrm{C}$ for 5 minutes, $25 \mu$ of enzyme reagent was added allowed to stand for 60 minutes then the temperature was raised to 62 ${ }^{\circ} \mathrm{C}, 100 \mu \mathrm{l}$ of probe reagent was added vortexed and incubated for 20 minutes to detect the amplicon, $25 \mu \mathrm{l}$ selection reagent was added vortexed and incubated for10minutes to differentiates between the hybridized and unhybridized probes, light emitted from the labeled DNA hybrids is measured as photon signals called Relative Light Units (R..LU) in a luminometer. The samples were also analyzed using positive and negative controls of genotype $16,18 / 45$ the positive ones are again analyzed using the same controls to rule out false positive. Final assay results were interpreted based on the analyte signal-to-cutoff $\mathrm{S} / \mathrm{CO}$ ) ratio described in the APTIMA HPV 16, 18/45 Genotype Assay manual (APTIMA).

\section{RESULTS}

Overall prevalence of HPV in the study area was $18.7 \% \mathrm{n}=56$ ), $79.3 \% \mathrm{n}=238$ ) were negative. Out of the positive samples obtained $51.7 \% \mathrm{n}=29$ ) were HPV 16 while $48.2 \% \mathrm{n}=27$ ) were HPV 18 and 45 as shown below (Fig. 1). 
The age grade 34-41 years had the highest prevalence rate of $25.6 \%$ followed by age grade 42 years above with a prevalence rate of $19.8 \%$ and $0 \%$ rate was recorded amongst age grade 18-25 years (Fig. 2). The results of this study have shown that there is a significant association between numbers of sexual partners and prevalence of HPV when analyzed statistically using Chi-Square at $95 \%$ confidence level (Table 1). However, HPV prevalence and occupation has been shown not to any association with one another when tested statistically using Chi-Square at $95 \%$ confidence interval (Table 2).

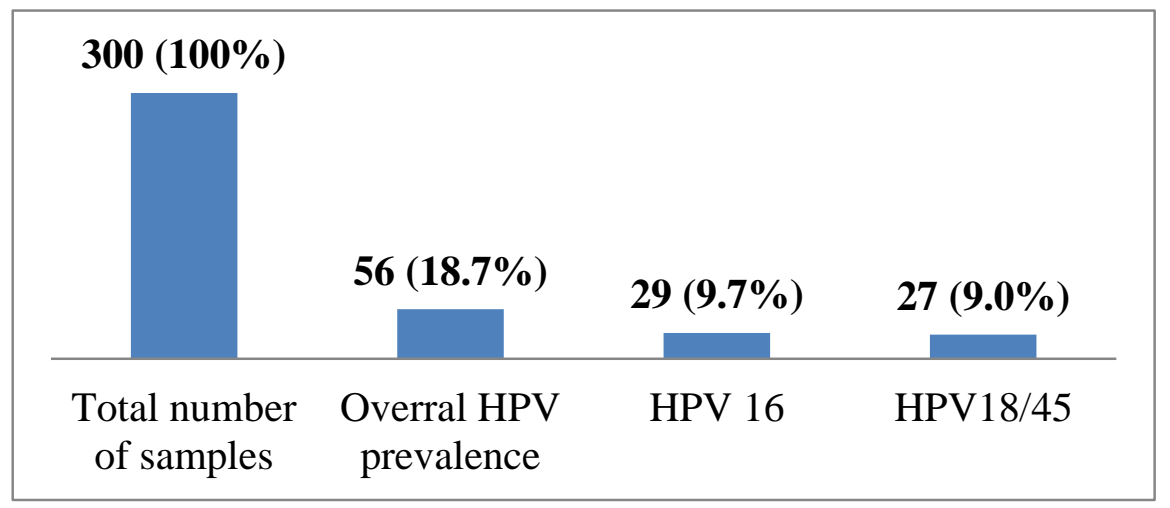

Figure 1: Prevalence of HPV among women of child bearing age in Adamawa State

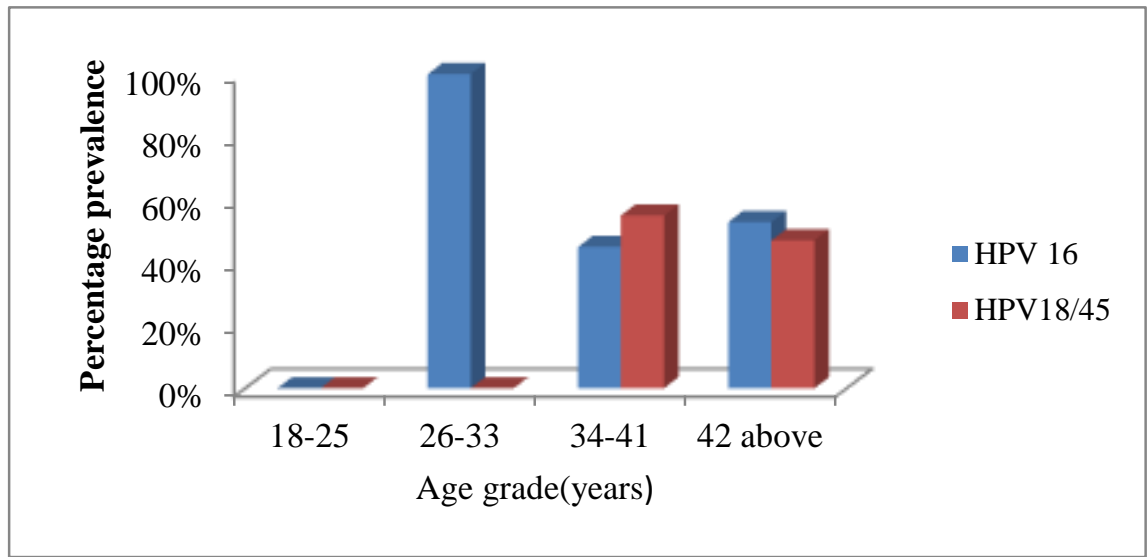

Figure 2. Prevalence of HPV genotype with respect to age

Table 1. Association between HPV prevalence and number of sexual partner

\begin{tabular}{|c|c|c|c|c|c|c|c|}
\hline \multirow[t]{3}{*}{ Age years) } & \multicolumn{6}{|c|}{ Number of Sexual Partner } & \multirow{3}{*}{ Total } \\
\hline & One & & Two & & Three a & above & \\
\hline & Pos & Neg & Pos & Neg & & Neg & \\
\hline $18-25$ & $0(0.2)$ & $15(5.6)$ & $0(2.2)$ & $6(7.8)$ & $0(3.3)$ & 0 12) & $\begin{array}{l}31 \\
(31.0)\end{array}$ \\
\hline $26-33$ & $0(0.1)$ & $4(3.4)$ & $1(1.3)$ & $4(4.8)$ & $1(2.0)$ & $9(7.3)$ & $\begin{array}{l}19 \\
(19.0)\end{array}$ \\
\hline $34-41$ & $0(0.5)$ & $9(14.0)$ & $7(5.5)$ & $21(19.5)$ & $13(8.3)$ & $28(30.2)$ & $\begin{array}{l}78 \\
(78.0)\end{array}$ \\
\hline 42 above & $2(1.1)$ & $\begin{array}{l}26 \\
(31.0)\end{array}$ & $13(12.0)$ & $44(43.0)$ & $18(18.3)$ & $69(66.0)$ & $\begin{array}{l}172 \\
(172.0)\end{array}$ \\
\hline Total & $22.0)$ & $\begin{array}{l}54 \\
(54.0)\end{array}$ & $21(21.0)$ & $75(75.0)$ & $32(32.0)$ & $116(116.0)$ & $\begin{array}{l}300 \\
(300.0)\end{array}$ \\
\hline
\end{tabular}

Pearson chi (15) $=30.9235, \mathrm{Pr}=0.009$

Values in the brackets are the expected frequencies.

Pos. Positive samples

Neg. Negative samples 
Table 2. Prevalence of HPV in association with occupation

\begin{tabular}{|c|c|c|c|c|c|c|c|c|c|c|c|}
\hline \multirow[t]{2}{*}{ Age-Grade } & \multicolumn{2}{|c|}{ Students } & \multicolumn{2}{|c|}{ Civil Servant } & \multicolumn{2}{|c|}{ Traders } & \multicolumn{2}{|c|}{ Housewives } & \multicolumn{2}{|c|}{ Farmers } & \multirow[t]{2}{*}{ Total } \\
\hline & Pos & Neg & Pos & $\mathrm{Neg}$ & Pos & Neg & Pos & Neg & Pos & Neg & \\
\hline $18-25$ & $\begin{array}{c}0 \\
(0.3)\end{array}$ & $\begin{array}{l}8 \\
(2.5)\end{array}$ & $\begin{array}{l}0 \\
(1.6)\end{array}$ & $\begin{array}{l}5 \\
(6.1)\end{array}$ & $\begin{array}{c}0 \\
(2.3)\end{array}$ & $\begin{array}{c}8 \\
7.4)\end{array}$ & $\begin{array}{l}0 \\
(0.7)\end{array}$ & $\begin{array}{c}6 \\
(4.5)\end{array}$ & $\begin{array}{c}0 \\
(0.9)\end{array}$ & $\begin{array}{c}4 \\
(4.7)\end{array}$ & $\begin{array}{c}31 \\
(31.0)\end{array}$ \\
\hline $26-33$ & $\begin{array}{l}0 \\
(0.2)\end{array}$ & $\begin{array}{l}1 \\
(1.5)\end{array}$ & $\begin{array}{l}0 \\
(0.9)\end{array}$ & $\begin{array}{l}2 \\
(3.7)\end{array}$ & $\begin{array}{c}1 \\
(1.4)\end{array}$ & $\begin{array}{c}3 \\
(4.6)\end{array}$ & $\begin{array}{l}0 \\
(0.4)\end{array}$ & $\begin{array}{c}4 \\
(2.8)\end{array}$ & $\begin{array}{c}1 \\
(0.6)\end{array}$ & $\begin{array}{c}7 \\
(2.9)\end{array}$ & $\begin{array}{c}19 \\
(19.0)\end{array}$ \\
\hline 34-41 & $\begin{array}{l}1 \\
(0.8)\end{array}$ & $\begin{array}{c}6 \\
(6.2)\end{array}$ & $\begin{array}{l}7 \\
(3.9)\end{array}$ & $\begin{array}{l}20 \\
15.3)\end{array}$ & $\begin{array}{c}8 \\
(5.7)\end{array}$ & $\begin{array}{c}19 \\
(18.7)\end{array}$ & $\begin{array}{l}2 \\
(1.8)\end{array}$ & $\begin{array}{c}6 \\
(11.4)\end{array}$ & $\begin{array}{c}2 \\
(2.3)\end{array}$ & $\begin{array}{c}7 \\
(11.7)\end{array}$ & $\begin{array}{c}78 \\
(78.0)\end{array}$ \\
\hline 42-above & $\begin{array}{l}2 \\
(1.7)\end{array}$ & $\begin{array}{l}9 \\
(13.8)\end{array}$ & $\begin{array}{l}8 \\
(8.6)\end{array}$ & $\begin{array}{l}32 \\
(33.8)\end{array}$ & $\begin{array}{c}13 \\
(12.6)\end{array}$ & $\begin{array}{c}42 \\
(41.3)\end{array}$ & $\begin{array}{l}5 \\
(4.0)\end{array}$ & $\begin{array}{l}28 \\
(25.2)\end{array}$ & $\begin{array}{c}6 \\
(5.2)\end{array}$ & $\begin{array}{c}27 \\
(25.8)\end{array}$ & $\begin{array}{c}172 \\
(172.0)\end{array}$ \\
\hline Total & $\begin{array}{l}3 \\
(3.0)\end{array}$ & $\begin{array}{l}24 \\
24.0)\end{array}$ & $\begin{array}{l}15 \\
(15.0)\end{array}$ & $\begin{array}{l}59 \\
(59.0)\end{array}$ & $\begin{array}{c}22 \\
(22.0)\end{array}$ & $\begin{array}{c}72 \\
(72.0)\end{array}$ & $\begin{array}{l}7 \\
\text { (7.0) }\end{array}$ & $\begin{array}{c}44 \\
(44.0)\end{array}$ & $\begin{array}{c}9 \\
(9.0)\end{array}$ & $\begin{array}{c}45 \\
(45.0)\end{array}$ & $\begin{array}{c}300 \\
(300.0)\end{array}$ \\
\hline
\end{tabular}

Pearson chi-square (27) $=40.9799 \mathrm{Pr}=0.041$

Values in the brackets are the expected frequencies.

Pos. Positive samples

Neg. Negative samples

\section{DISCUSSION}

The prevalence of HPV positivity of $18.7 \%$ found in this study in some part of Adamawa state; Nigeria is consistent with previous reports of the elevated prevalence of HPV in women in Nigeria and Sub-Saharan Africa. Studies carried out in Ibadan Nigeria showed a prevalence of $26.3 \%$ in a population base study according to Thomas et al., (2004). Prevalence of $66.10 \%$ was reported in Burkina-Faso (Didelot-Roussen et al., 2006). HPV surveys in sub-Saharan Africa have generally shown relatively high HPV prevalence with some variation, depending on how women were selected, and how HPV was tested. For example, $17 \%$ prevalence of high-risk HPV types was found in rural Uganda (Serwada et al., 1999), while $25 \%$ prevalence was found among HIV-negative women in Harare, Zimbabwe (Womack et al., 2000). Prevalence of $18 \%$ was also recorded in Dakar and Pikene, Senegal (Xi and Toure, 2006). Prevalence of HPV with specific genotype shows that HPV 16 has the highest prevalence with the highest rate amongst age grade 26- 33 years, followed by HPV $18 / 45$ with the highest rate amongst age grade $34-41$ years. This finding is in line with some work carried out in some Africa countries, with variations in the relative ranking of HPV types that are compatible with chance and everywhere the predominance of HPV 16 and 18 rises with the increasing severity of cervical findings (Clifford et al., 2003). Also type-specific distribution of HPV among cervical cancer biopsies from Africa showed that HPV 16 accounted for $50.2 \%$ of samples, HPV 18 for $14.1 \%$, and HPV 45 for $7.9 \%$ i.e., a distribution similar to that found worldwide) [Clifford et al., 2006]. The age pattern of HPV prevalence also differs somewhat from one country to another. The predominant pattern includes an early peak, soon after the start of sexual intercourse (Jacobs et al., 2000, Kiaer et al., 2001), followed by lower levels of HPV positivity in middle age [Jacobs et al., 2000, Annh et al.,2003, Sanjose et al., 2003]. In three studies from sub-Saharan Africa (Serwada et al.,1999, Castellsague et al., 2001, DeVust et al., 2003), the prevalence of HPV declined with an increased in age. In contrast, a study by Xi et al. (Xi and Toure, 2006) indicated that high-risk, but not low-risk HPV types, were more frequently detected in older than younger women.

According to Nweke et al., (2013) older females between the ages of 25-34 years were more likely to be infected with high risk HPVs than those less than 25 years and those 55years and above. This is similar to what was discovered in this study and among HIV positive Rwandan women in whom prevalence peaked in those aged 25-34years and declined in those greater than 55 years old (Singh et al., 2009). This may be explained by the time taken for persistence to develop in the 25-34 years age range and the lower incidence of sexual activity in the $>55$ years age range.

Statistical analysis of HPV prevalence based on the number of sexual partners shows that there is significant association between number of sexual partner and HPV prevalence as majority of the positive subjects are having more number of sexual partners. This is in line with World Health Organization (WHO, 2006) report that risk factors for persistent HPV infections include early age of first sexual intercourse, multiple sexual partners, smoking, and poor immune function. Bosch, et al. (2006) also reported that HPV is transmitted by direct skin-to-skin contact with vaginal and anal sex being the most common methods. Occasionally, it can spread from a mother to her baby during pregnancy. It does not spread via common items like toilet seats. 
People can become infected with more than one type of HPV. HPV only affects humans, genital HPV infections are considered to occur predominantly, although not exclusively, through sexual transmission (Bosch et al., 2006).

\section{CONCLUSION}

This research investigates high-risk type of HPV among women of childbearing age in some communities and those attending hospitals in Adamawa State. Out of the 300 samples analyzed, $56(18.7 \%)$ are positive, $238(79.3 \%)$ are negative for HPV, and $6(2 \%)$ are invalid. Out of the positive samples obtained, $29(51 \%)$ were HPV 16 while 27 (48.2\%) were HPV 18/45; the study also showed that the age grade of 24-41 years has the highest prevalence of $25.6 \%$. No positive sample was found among age grades of 18-23. At $P \leq 0.05$, the result shows that HPV prevalence is significantly associated with the the number of sexual partners of an individual $(P=0.009)$. The majority of those positives samples are from individuals engaged in multiple

\section{REFERENCES}

Cohen, J. (2005) public health HPVs peculiarities from infection to disease. Science Journal Vol. 29: 308- 319

Center for Disease Control (CDC, 2006): Sexually Transmitted disease treatment guideline available online from https www.cdc.gov

Hildshein A., M. H. Schiffman, P. E Gravitt., A.G. Glass, C.E. Greer, T. Zhang, D. R. Scott, B.B. Rush, P. Lawler, M. E. Sherman (1994): Persistence of type specific human papillomavirus infection among cytologically normal women.Journal of Infectious Diseases 169:235-240

Monsonego J., F.X. Bosch, P. Coursaget, J. T. Cox, E. Franco, I. Frazer, T. C. Wright, R. Sankaranarayanan, J. Schiller, A. Singer, W. Jr. Kinney, C. J.S. Meije, J. Linder, D.M Parkin, J. Ferlay, M. Hamdi-Cherif, F. Sitas, J.O.Thomas, H. Wabbinga, S.I. Whelan (2003): Cancer in Africa Epidemiology and Prevention of cervix cancer. IARC Scientific Publication No 153, LYON:IARC Press pp268-276

Safaein M., M. Schiffman, J. Gage, D. Solomon, C. Wheeler, P. Castle (2009): Detection of precancerous cervical lesion is differentiated by Human Papillomavirus type. Cancer Research. 69 (8):3262-3266

Walboomer J.M, M.V. Jacobs, M.M. Manos, F.X. Bosch, J. A. Kummer, K. V. Shah, J. Snijder, J. Peto, C. J. Meije, N. Munoz

sexes. Based on this finding, the prevalence of $\mathrm{HPV}$ in Adamawa state is as high as it is reported in some parts of Nigeria. Based on this finding, the prevalence of HPV in Adamawa state is as high as it is reported in some parts of Nigeria. Based on this finding, the prevalence of HPV in Adamawa state is as high as it is reported in some parts of Nigeria. Based on this finding, the prevalence of HPV in Adamawa state is as high as it is reported in some parts of Nigeria. Based on this finding, the prevalence of HPV in Adamawa state is as high as reported in some parts of Nigeria and sub-Sahara Africa.

\section{Contribution to knowledge}

This project provides base line information on the prevalence of high-risk Human papilloma Virus among women of child bearing age in Adamawa State

\section{Acknowledgements}

We are very grateful to Mr. Andrew Ivo Emo and staff of Defence Reference Laboratory Abuja for their assistance in carrying out the analysis.

(1999): Human papillomavirus is a necessary cause of invasive cervical cancer Worldwide. Journal of Pathology.Vol. 189:12-19

Thomas J.O., R. Herrero, A.A. Omigbodun, K. Ojemakinde, I.O. Ajayi, A. Fawole (2004): Prevalence of papillomavirus infection in women in Ibadan Nigeria: A population-based study. British Journal of Cancer Vol.90 (3): 638-645

Map of Adamawa State Available online from www.adamawastate.com

Naing L., T. Winn, B.N. Rushi (2006): Practical issue in calculating the sample size for prevalence studies. Journal Archieve of Orofacial science Vol.1: 9-14

APTIMA $®$ HPV 16 18/45 Genotype Assay. https: / /www.accessdata.fda.gov/cdrh_ docs/pdf12/P120007c.

Didelot-Rousseau M.N., N. Nagot, V. Costes-Maritineau, X. Valles, A. Ouedraogo, I. Konate (2006): Human papilloma virus genotype distribution and cervical squamous intraepithelial lesions among high risk women with and without HIV-1 infection in Burkina Faso. British Journal of Cancer; Vol. 95 (3):355-62

Serwadda D., M. J. Wawer, K.V. Shah, N.K. Sewankambo, R. Daniel, C. Li, A. Lorincz, M.P. Meehan, F. Wabwire-Mangen, R.. H. Gray. (1999) Use of a hybrid capture assay of self-collected vaginal swabs in rural Uganda for detection of human papillomavirus. Journal of Infectious Diseases. 180:1316-1319 
UJMR, Volume 6 Number 2, December, 2021, pp 19 - $24 \quad$ ISSN: 2616 - 0668

Womack S.D., Z.M. Chirenje, L. Gaffikin P.D. Blumenthal, J. A. McGrath, T. Chipato, S. Ngwalle, M. Munjoma, K.V. Shah (2000): HPV-based cervical cancer screening in a population at high risk for HIV infection. International Journal Cancer; Vol. 85:206-210

Xi L.F.and Toure P. (2006): HPV genotype distribution and squamous intraepithelial lesions among high-risk women with and without HIV-1infection in Burkina faso. British Journal for Cancer Vol. 95:355-362

Clifford G. M., Smith J.S, M. Plummer, N. Muñoz, S. Franceschi (2003). Human Papilloma virus types in invasive cervical cancer worldwide: a meta-analysis. British Journal for Cancer; Vol. 88:63-73.

Jacobs V. M., J. M. Walboomers, P. J. Snijders, F. J. Voorhorst, R. H. Verheijen, N. Fransen-Daalmeijer, C.J Meijer (2000). Distribution of 37 mucosotropic HPV types in women with cytologically normal cervical smears: the age-related patterns for high-risk and low-risk types. International Journal for Cancer. Vol.87:221-227

Kjaer S.K., B. Chackerian, A.J.C. van der Brule, E.I. Svare, I.G. Paul, J.M.M. Walboomers, J. T. Schiller, J. E. Bock, M.E., Sherman, D.R Lowy, C.J.L.M., Meijer (2001). High-Risk Human Papilloma Virus Is Sexually Transmitted: Evidence from a Follow-up Study ofVirgins Starting Sexual Activity Intercourse) Cancer Epidemiology Biomark Prevention, Vol.10:101-105

Anh P.T.H, N.T. Hieu, R. . Herrero (2003). Human papillomavirus infection among women in South and North Vietnam. International Journal of cancer.Vol.104:213-220

De Sanjose S., R. Almirall, B. Lloverus, R. Front,
M. Diaz, N. Murioz, I. Catala, C. J. Meijer, P. j. Snijders, R.. Herrero, F. X. Bosch (2003). Cervical human Papilloma virus Infection in the Female Population in Barcelona, Spain. Sexually Transmitted Diseases. Vol.30: 788 - 793

Castellsague X., C. Menendez, M. P. Loscertales, J. R. Kornegay, F. dos Santos, F.X., Gomez-Olive, B., L. Loveras, N., Abarca, N Vaz., A Barreto.., F.X Bosch,., P Alonso (2001). Human papillomavirus genotypes in rural Mozambique. Lancet; Vol.358:1429-1430

De Vuyst H., S. Steyaert, L. Van Renterghem, P. Claeys, L. Muchiri, S. Sitati, S. Vansteelandt, W. Quint, B. Kleter, E. Van Marck, M. Temmerman (2003). Distribution of human Papilloma virus in a family planning population in Nairobi, Kenya. Sexually Transmitted Diseases. Vol.30:137-142

Nweke I.G., A. A. F. Banjo, F. B. Abdulkareem, V.U. Nwadike (2013). Prevalence of Human Papilloma Virus DNA in HIV Positive Women in Lagos University Teaching Hospital LUTH) Lagos, Nigeria. British Microbiology Research Journal. Vol.3 (3): 400-413

Singh, K. Anastos, D. R. Hoover, R. D. Burk, Q. Shi, L. Ngendahayo (2009). Human papilloma virus infection and cervical cytology in HIV infected and HIV uninfected Rwandan women. Journal of Infectious Diseases Vol.199 (12):1851-61

World Health Organization (2006): Cervical cancer, Human Papilloma virus and HPV cervical. WHO/RHR/08.14

Bosch F.X., Y. L. Qiao, X. Castellsague (2006). The epidemiology of human Papilloma virus infection and its screening. International journal of gynecology and obstetrics. Vol.94: 1-8 